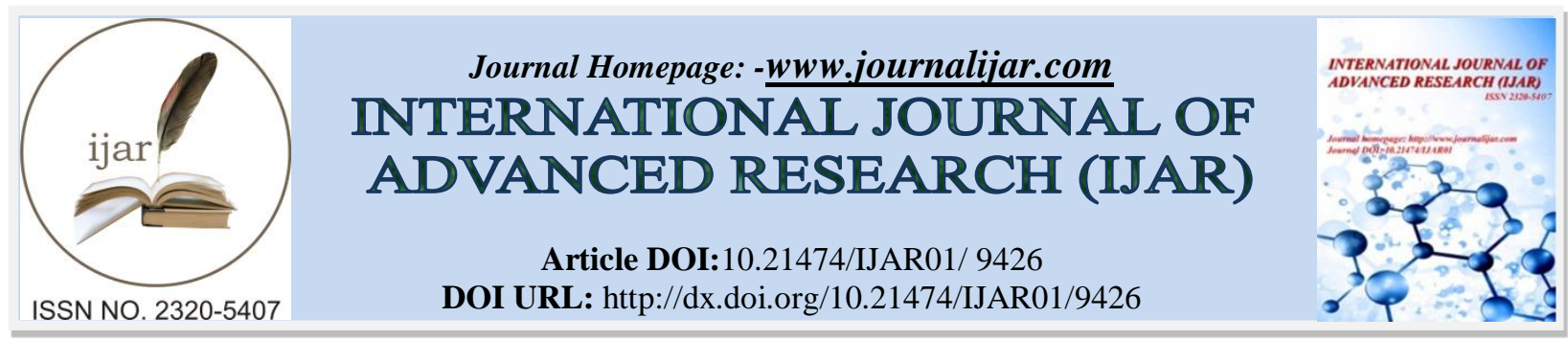

RESEARCH ARTICLE

\title{
BACTERICIDAL AND BACTERIOSTATIC POTENCY OF SOME PHYTO-BACTERICIDES AGAINST SELECTED ESBL PRODUCING BACTERIA.
}

\author{
Andy I.E., Tiku, D.R., Okpo E.A., Utsalo S.J. and Mboto C.I.
}

Department of Microbiology, Faculty of Biological Sciences, University of Calabar-Nigeria.

\section{Manuscript Info}

Manuscript History

Received: 22 May 2019

Final Accepted: 24 June 2019

Published: July 2019

\begin{abstract}
The study to investigate the bactericidal and bacteriostatic potency of some phyto-bactericides against selected ESBL producing bacteria was carried out. Methanolic leaf extracts of Chromoleana odorata, Lasianthera ofricana, Heinsia crinata, Piper guineense, Aspilia africana and Lasianthera afrciana were tested against ESBL producing $E$. coli and $K$. pneumonia isolated from clinical specimens (urine, wound swabs, stool, blood, high vaginal swab and sputum obtained from hospitals in five of the six states of the South-South geo-political zones of Nigeria namely; Akwa-Ibom, Cross-River, Delta, Edo and Rivers States) using both the agar disc diffusion and agar well diffusion method. Results obtained from the study revealed that all the plant extracts showed varying degree of antibacterial potency against the ESBL producing E.coli and K. pneumonia. The zones of inhibition increased with a corresponding increase in the concentration of the plant leaf extracts, with higher zones of inhibition observed at 300 $\mathrm{mg} / \mathrm{ml}(13.2 \pm 0.25$ and $20.4 \pm 0.11 \mathrm{~mm}$ (C. odorata); $17.1 \pm 0.09$ and $18.3 \pm 0.25 \mathrm{~mm}$ (A. Africana); $19.8 \pm 0.73$ and $10.8 \pm 0.25 \mathrm{~mm}$ (H. crinata); $19.2 \pm 0.39$ and $24.3 \pm 0.39 \mathrm{~mm}$ ( $P$. guineense); $15.5 \pm 0.42$ and $18.5 \pm 0.03 \mathrm{~mm}$ (L. africana) as against the ESBL producing E. coli and $K$. pneumonia respectively). Although, $P$. guineense showed the least minimum inhibitory concentration $(50 \mathrm{mg} / \mathrm{ml})$ against the isolates, however the MIC of the plant extracts recorded were higher than that observed with the conventional antibiotic gentamicin $(1.5 \mathrm{mg} / \mathrm{ml})$. The study has revealed that the phyto- constituents of $C$. odorata, $A$. africana, $H$. crinata, $P$. guineense and $L$. africana, have high antimicrobial property as compared and confirmed with commercial antibiogram. Hence, these plants could serve as an alternative medicine without side effects and in addition they could further be used to discover other bioactive natural products that may serve as lead for the development of new phyto-pharmaceuticals.
\end{abstract}

Copy Right, IJAR, 2019,. All rights reserved.

\section{Introduction:-}

ESBLs are known as extended spectrum because they are able to hydrolyze a broader spectrum of $\beta$-lactam antibiotics than the simple parent $\beta$-lactamases from which they are derived (Andy et al., 2019). They have ability to

Corresponding Author:-Andy I.E.

Address:-Department of Microbiology, Faculty of Biological Sciences, University of Calabar-Nigeria. 
even inactivate $\beta$-lactam antibiotics containing an oxyimino-group such as oxyimino- cephalosporin as well as oxyimino-monobactam (Ikegbunam et al., 2014). They are not active against cephamycins and carbapenems. Generally, they are inhibited by $\beta$-lactamase- inhibitors such as clavulanate and tazobactem (Muza heed et al., 2008). ESBLs have been found in a wide range of gram-negative rods. However, the vast majority of species expressing these enzymes belong to the family Enterobacteriaceae (Kiratisin et al., 2007).

Medicinal plants provide basic raw materials for different industries such as pharmaceutical, cosmetic, perfumery and food (Varalakshmi et al, 2014). The medicinal plants are referred to as plants that are used for their therapeutic or medicinal values (Mukesh et al., 2018). The whole plant or its different parts may be valued for its therapeutic, medicinal, aromatic or savory qualities (Sahid et al., 2003). They also play vital role as an antimicrobial agent. There has been resurgence in the consummation and demand for medicinal plants. Many plants components are now synthesized in large laboratories for their use in pharmaceutical preparations. A wide range of secondary metabolites are produced by plants which can be directly used as precursors or as principal compound for drug synthesis in pharmaceutical industries (Agbafor et al., 2011). It is anticipated that plant extracts exhibiting target sites other than those used by antibiotics can be effective against microbial pathogens which are drug resistant. Bioactive compounds are normally accumulated as secondary metabolites in all plant cell but their concentration is determined by the plant part, climate and growth phase (Dhiman et al., 2011). The highest concentration of such compounds is present in leaves generally preferred for therapeutic use (Dhiman et al., 2011).

The antimicrobial activity of extracts of various plants has been proven scientifically. These extracts contain multiple active ingredients which could deter the development of resistance. Currently, there are few medicinal plants that have been established to have antimicrobial activity against ESBL producing organisms, hence the need for this present study.

\section{Material And Methods:- \\ Test microorganism}

The test organism used in this study were ESBL producing bacteria isolates obtained from various clinical specimens (urine, wound swab, stool, blood, high vaginal swab and sputum) from two hospitals in five out of the six states of the South-South geopolitical zones namely; Akwa-Ibom (University of Uyo Teaching Hospital and St. Luke's Hospital Anua in Uyo), Cross River (University of Calabar Teaching Hospital and General Hospital, Calabar), Delta (Federal Central Hospital Asaba and NNPC Clinic, Warri), Edo (University of Benin Teaching Hospital and Central Specialist Hospital, Benin) and Rivers (University of Port Hartcourt Teaching Hospital and Brait Waite-Memorial Hospital, Port Hartcourt).

\section{Herbal extract}

The plants used for this study were Chromoleana odorata, Aspilia africana, Heinsia crinata, Piper guineense and Lasianthera africana. They were identified and authenticated by a taxonomist in the Department of Plant and Ecological studies, University of Calabar, and voucher specimens were deposited there. The leaf parts were air-dried at room temperature and reduced into fine powders using a mechanical blender. $100 \mathrm{~g}$ of the powdered materials were extracted using $100 \mathrm{ml}$ analytical grade methanol (BHD laboratory, England) via cold maceration for forty eight hours. The resulting mixture was filtered and the filtrate was concentrated using a Rotary evaporator (Model RE 300, Barloworld Scientific Ltd, UK) and kept at room temperature for the methanol to completely evaporate for $24 \mathrm{hrs}$. The resulting residue which was the methanol leaf extract of the various plants was stored in air-tight containers. 


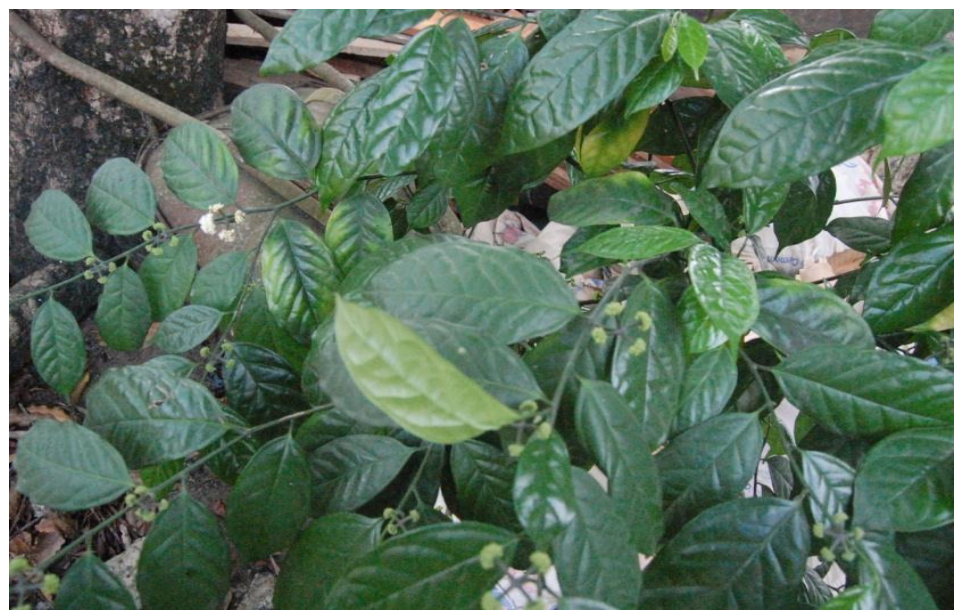

Plate 1:-Lasianthera africana

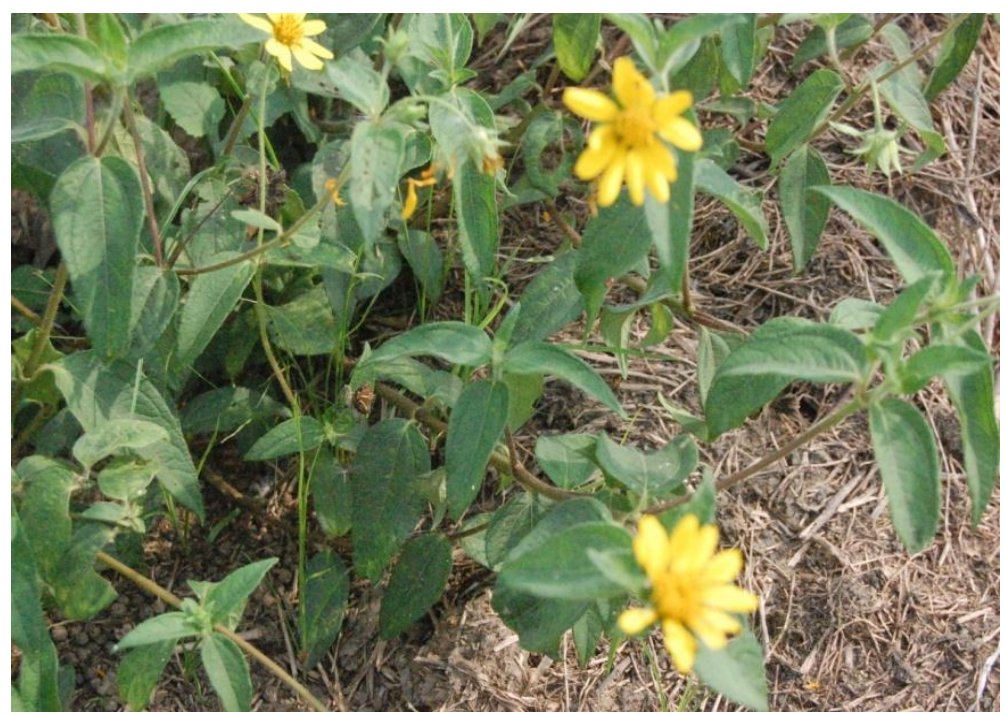

Plate 2:-Aspilia Africana

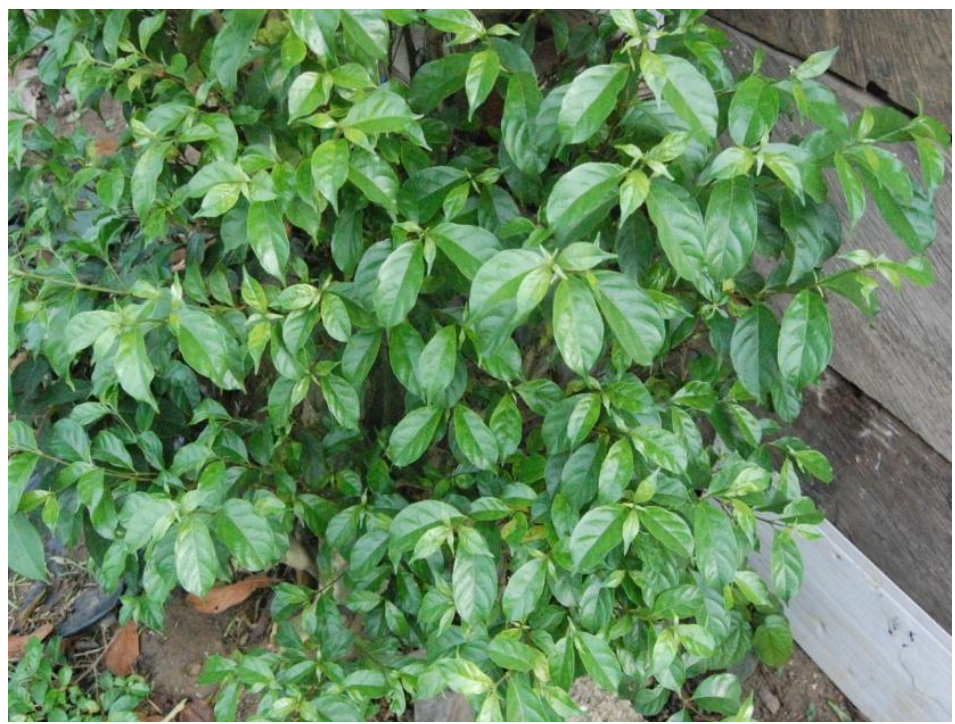

Plate 3:-Heinsia crinata 


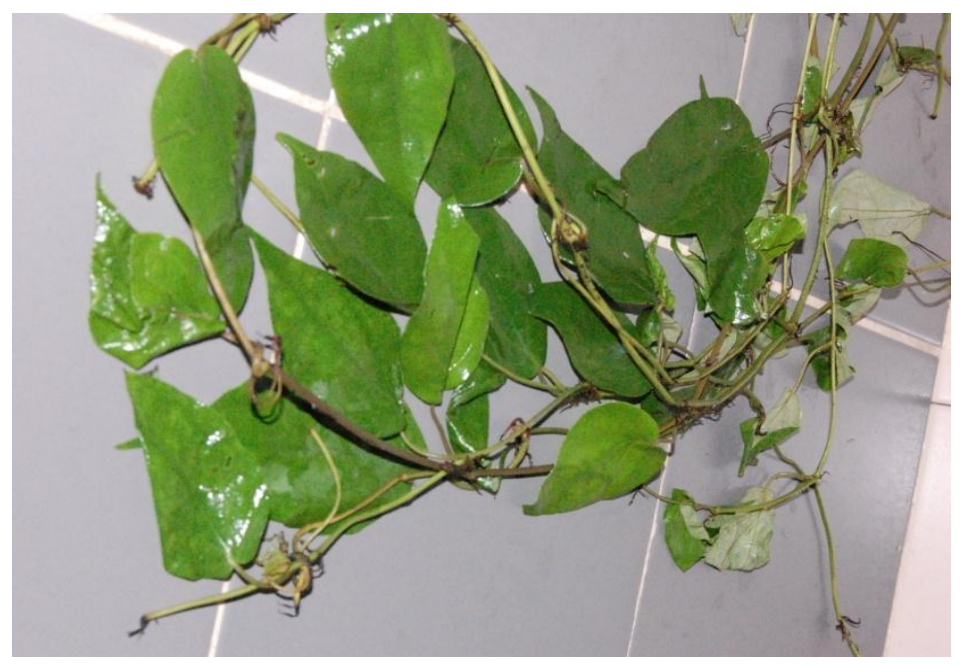

Plate 4:-Piper guineense

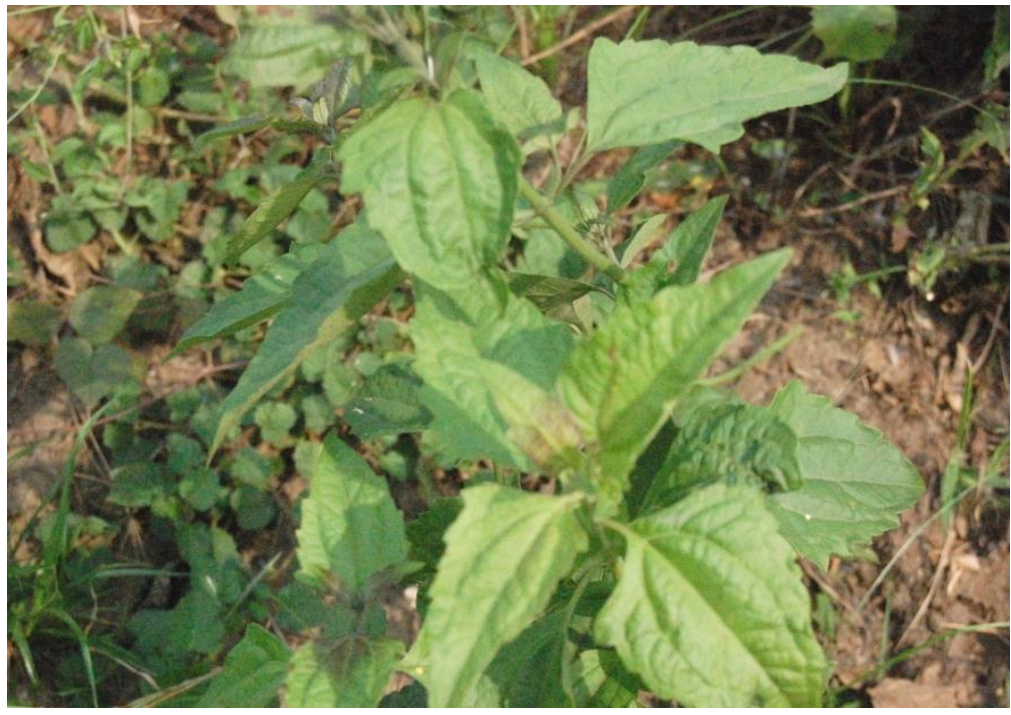

Plate 5:-Chromolaena odorata

\section{Standard stock solutions}

Standard stock solutions of $50 \mathrm{mg} / \mathrm{ml}, 100 \mathrm{mg} / \mathrm{ml}, 150 \mathrm{mg} / \mathrm{ml}, 200 \mathrm{mg} / \mathrm{ml}, 250 \mathrm{mg} / \mathrm{ml}$ and $300 \mathrm{mg} / \mathrm{ml}$ of Chromoleana odorata, Aspilia africana, Heinsia crinata, Piper guineense and Lasianthera africana leaves respectively, were prepared in dimethylsulphoxide (DMSO, BDH-Laboratory, England). Two-fold serial dilutions of the stock solutions were prepared while carrying out the various tests. $100 \mu \mathrm{g} / \mathrm{ml}$ stock solution of gentamicin was diluted to obtain concentrations of $0.5 \mathrm{mg} / \mathrm{ml}, 1.0 \mathrm{mg} / \mathrm{ml}, 1.5 \mathrm{mg} / \mathrm{ml}, 2.0 \mathrm{mg} / \mathrm{ml}$ and $2.5 \mathrm{mg} / \mathrm{ml}$, which were used in this study.

\section{Sensitivity of ESBL producing organisms to the plant extracts and standard antibiotics.}

This was determined by using the disc diffusion method for the standard antibiotics and agar well diffusion method for the plant extracts (CLSI, 2012). Briefly, a Petri-dish was divided into five sections; one section for the stock solution and each dilution of a plant extract in DMSO. $0.1 \mathrm{ml}$ of the standardized suspension of the isolates were put into the empty sterile petri-dish. Bijou bottles containing $20 \mathrm{ml}$ of sterile molten Mueller- Hinton agar at $45^{\circ} \mathrm{C}$ was poured into each of the plates containing the suspension of the isolate. These were gently rotated thoroughly and were allowed to set for 20 minutes. Six millimeters $(6 \mathrm{~mm})$ cork borer dimension was used to boreholes into each section in the plates and each section was labeled properly. About $40 \mu \mathrm{l}$ of the various concentrations of the extracts were placed into the wells and left for one hour at room temperature. The plates were incubated at $37^{\circ} \mathrm{C}$ for $18-24$ hours. The test was carried out in triplicates for each isolates. The experiment was carried out with all the plant

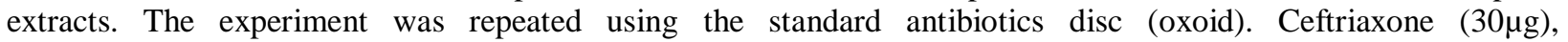
Chloramphenicol $(30 \mu \mathrm{g})$, Ciprofloxacin $(30 \mu \mathrm{g})$, Amoxicillin $(30 \mu \mathrm{g})$, Gentamicin $(30 \mu \mathrm{g})$, Imipenem $(30 \mu \mathrm{g})$, and 
Tetracycline $(30 \mu \mathrm{g})$ were placed on each section of the plate, up to a maximum of five sections. After the incubation period, the plates were observed and inhibition zone diameters (IZD) were measured.

\section{Evaluation of the minimum Inhibitory Concentration (MIC) of the plant extract}

The minimum inhibitory concentration of the extracts against E. coli and $\mathrm{K}$. pneumonia expressing ESBL were performed using the agar dilution method (Chah et al., 2006). $19 \mathrm{mls}$ of sterilized molten nutrient agar was aseptically poured into sterile petri-dishes containing $1 \mathrm{ml}$ of the graded concentrations of the extracts. The plates were rotated to ensure even distribution of the plant extracts and allowed to set. The plates were swabbed with $0.05 \mathrm{ml}$ of standard suspension of the ESBL producing E. coli and $\mathrm{K}$. pneumonia isolates. The plates were incubated at $37^{\circ} \mathrm{c}$ for $18-24$ hours. The presence of growth was observed after incubation.

\section{Results:-}

Antibiogram of ESBL producing E.coli and K. pneumonia isolates

The antibiogram of the ESBL producing E. coli and K. pneumonia isolates is shown in Table 1 below. The isolates were multi- drug resistant. They were resistant to amoxicillin and chloramphenicol but were sensitive to ciprofloxacin, gentamicin, ceftriaxone, erythromycin, tetracycline and imipenem.

Sensitivity of the ESBL producing E. coli and K. pneumonia to the plant extracts

Table 2 present the result of the antimicrobial activity of the methanolic leaf extract of C. odorata on ESBL producing E. coli and K. pneumonia. it showed that a higher zone of inhibition of $13.2 \pm 0.25 \mathrm{~mm}$ and $20.4 \pm 0.27 \mathrm{~mm}$ was recorded at $300 \mathrm{mg} / \mathrm{ml}$, when the extract was tested against E.coli and K. pneumonia respectively. Similarly, Table 3 present the result of antimicrobial activity of the methanolic leaf extract of A. Africana on ESBL producing E. coli and K. pneumonia. it showed that the zones of inhibition increased with a corresponding increase in the concentrations of the plant extract. However, a higher zone of inhibition $(17.1 \pm 0.09 \mathrm{~mm}$ and $18.3 \pm 0.25 \mathrm{~mm})$ was observed at $300 \mathrm{mg} / \mathrm{ml}$, when the extract was tested against ESBL producing E. coli and K. pneumonia respectively. The result of the antimicrobial activity of the methanolic leaf extract of H. crinata, P. guineense and L. Africana against ESBL producing E. coli and K. pneumonia are presented in Table 4, 5 and 6 respectively. At a concentration of $300 \mathrm{mg} / \mathrm{ml}$, a higher zones of inhibition $(19.8 \pm 0.73$ and $10.8 \pm 0.25 \mathrm{~mm} ; 19.2 \pm 0.39$ and $24.3 \pm 0.39 \mathrm{~mm} ; 15.5 \pm 0.42$ and $18.5 \pm 0.43 \mathrm{~mm}$ ) were observed when extracts of $\mathrm{H}$. crinata, P. guineense and L. africana were tested against ESBL producing E. coli and K. pneumonia.

The result of the minimum inhibitory concentration of the plant extracts against the ESBL producing E. coli and K. pneumonia is presented in Table 7. It showed that P. guineense had the lowest minimum inhibitory concentration $(50 \mathrm{mg} / \mathrm{ml})$ as compared to that observed with the other extracts tested against the ESBL producing E. coli and $\mathrm{K}$. pneumonia.

Table 1:-Antibiogram of ESBL producing E.coli and K. pneumonia before treatment with methanolic leaf extracts

\begin{tabular}{|l|l|l|l|l|l|l|l|l|}
\hline & \multicolumn{7}{|c|}{ Inhibition zone diameter of Antibiotics (mm) } \\
\hline Isolate & CHL & AMX & CIP & GEN & CEF & ERY & TET & IMP \\
\hline E. coli & 0 & 0 & 14 & 13 & 12 & 13 & 18 & 29 \\
\hline K. pneumonia & 0 & 5 & 16 & 15 & 14 & 16 & 20 & 31 \\
\hline
\end{tabular}

Keys: CHL- Chloramphenicol, AMX- Amoxicillin, CIP- Ciprofloxacin, GEN- Gentamicin, CEF- Ceftriaxone, ERY - Erythromycin, TET- Tetracycline, IMP- Imipenem

Table 2:-Antimicrobial activity of the methanolic leaf extract of C. odorata on ESBL producing E. coli and K. pneumonia

\begin{tabular}{|l|l|l|}
\hline \multicolumn{3}{|c|}{ Zones of inhibition $(\mathbf{m m})$} \\
\hline Concentration $\mathbf{( m g / m l )}$ & E. coli & K. pneumonia \\
\hline 50 & $3.1 \pm 0.18$ & $6.4 \pm 0.19$ \\
\hline 100 & $5.3 \pm 0.19$ & $8.6 \pm 0.21$ \\
\hline 150 & $7.4 \pm 0.21$ & $11.8 \pm 0.24$ \\
\hline 200 & $9.3 \pm 0.23$ & $15.7 \pm 0.25$ \\
\hline 300 & $13.2 \pm 0.25$ & $20.4 \pm 0.27$ \\
\hline
\end{tabular}

*Each value represents the mean value of two determinants 
Table 3:-Antimicrobial activity of the methanolic leaf extract of A. africana on ESBL producing E. coli and K.pneumonia

\begin{tabular}{|l|l|l|}
\hline \multicolumn{3}{|c|}{ Zones of inhibition $(\mathbf{m m})$} \\
\hline Concentration $(\mathbf{m g} / \mathbf{m l})$ & E. coli & K. penumoniae \\
\hline 50 & $5.2 \pm 0.7$ & $6.4 \pm 0.18$ \\
\hline 100 & $7.8 \pm 0.06$ & $9.2 \pm 0.19$ \\
\hline 150 & $11.5 \pm 0.06$ & $12.8 \pm 0.20$ \\
\hline 200 & $14.3 \pm 0.08$ & $15.3 \pm 0.24$ \\
\hline 300 & $17.1 \pm 0.09$ & $18.3 \pm 0.25$ \\
\hline
\end{tabular}

*Each value represents the mean value of two determinants

Table 4:-Antimicrobial activity of the methanolic leaf extract of H. crinata on ESBL producing E. coli and K. pneumonia

\begin{tabular}{|l|l|l|}
\hline \multicolumn{3}{|c|}{ Zones of inhibition $\mathbf{( m m})$} \\
\hline Concentration $(\mathbf{m g} / \mathbf{m l})$ & E. coli & K. penumoniae \\
\hline 50 & $4.7 \pm 0.16$ & $2.1 \pm 0.18$ \\
\hline 100 & $7.9 \pm 0.21$ & $3.8 \pm 0.21$ \\
\hline 150 & $11.2 \pm 0.43$ & $6.4 \pm 0.22$ \\
\hline 200 & $15.4 \pm 0.56$ & $7.3 \pm 0.22$ \\
\hline 300 & $19.8 \pm 0.73$ & $10.8 \pm 0.25$ \\
\hline
\end{tabular}

*Each value represents the mean value of two determinants

Table 5:-Antimicrobial activity of the methanolic leaf extract of P. guineense on ESBL producing E. coli and K. pneumonia

\begin{tabular}{|l|l|l|}
\hline \multicolumn{3}{|c|}{ Zones of inhibition (mm) } \\
\hline Concentration $(\mathbf{m g} / \mathbf{m l})$ & E. coli & K. pneumonia \\
\hline 50 & $4.3 \pm 0.18$ & $6.4 \pm 0.21$ \\
\hline 100 & $7.4 \pm 0.24$ & $11.8 \pm 0.28$ \\
\hline 150 & $11.6 \pm 0.29$ & $14.9 \pm 0.31$ \\
\hline 200 & $15.3 \pm 0.31$ & $18.6 \pm 0.32$ \\
\hline 300 & $19.2 \pm 0.39$ & $24.3 \pm 0.30$ \\
\hline
\end{tabular}

*Each value represents the mean value of two determinants

Table 6:-Antimicrobial activity of the methanolic leaf extract of L. africana on ESBL producing E. coli and K. pneumonia

\begin{tabular}{|l|l|l|}
\hline \multicolumn{2}{|c|}{ Zones of inhibition $(\mathbf{m m})$} \\
\hline Concentration $(\mathbf{m g} / \mathbf{m l})$ & E. coli & K. pneumonia \\
\hline 50 & $4.2 \pm 0.24$ & $5.6 \pm 0.25$ \\
\hline 100 & $7.3 \pm 0.28$ & $8.4 \pm 0.29$ \\
\hline 150 & $9.4 \pm 0.31$ & $12.5 \pm 0.31$ \\
\hline 200 & $11.6 \pm 0.39$ & $15.9 \pm 0.38$ \\
\hline 300 & $15.5 \pm 0.42$ & $18.5 \pm 0.43$ \\
\hline
\end{tabular}

*Each value represents the mean value of two determinants

Table 7:-Minimum inhibitory concentration of the plant extracts against the ESBL producing E. coli and K. pneumonia

\begin{tabular}{|c|c|c|c|c|c|c|}
\hline & \multicolumn{5}{|c|}{ Minimum inhibitory concentration } & \\
\hline Isolates & $\begin{array}{l}\text { C. odorata } \\
(\mathrm{mg} / \mathrm{ml})\end{array}$ & $\begin{array}{l}\text { A. africana } \\
(\mathrm{mg} / \mathrm{ml})\end{array}$ & $\begin{array}{l}\text { H.crinata } \\
(\mathrm{mg} / \mathrm{ml})\end{array}$ & $\begin{array}{l}\text { P.guineense } \\
(\mathrm{mg} / \mathrm{ml})\end{array}$ & $\begin{array}{l}\text { L. africana } \\
(\mathrm{mg} / \mathrm{ml})\end{array}$ & $\begin{array}{l}\text { Gentamicin } \\
(\mathrm{mg} / \mathrm{ml})\end{array}$ \\
\hline E. coli & 100 & 50 & 50 & 50 & 100 & 1.5 \\
\hline K.pneumoniae & 50 & 100 & 100 & 50 & 100 & 1.5 \\
\hline
\end{tabular}




\section{Discussion:-}

In this study, the sensitivity of ESBL producing E. coli and K. pneumonia to imipenem was not surprising, as it is in accordance with previous studies by Pena et al., (1998) and Winokur et al., (2001). The resistance of the isolates to amoxicillin and chloramphenicol could be due to the co-existence of genes encoding drug resistance to other antibiotics on the plasmids which encode ESBLs (Ikegbunam et al., 2014). The methanolic leaf extracts of all the plants used (C. odorata, A. africana, H. crinata, P. guineense and L. africana) showed varying degree of antimicrobial activities against the ESBL producing E. coli and K. pneumonia tested. However, the zones of inhibition observed with the plant extracts increased with a corresponding increase in the concentrations of the extracts. This observation was not surprising as similar study by Hrindhya and Kulandhaivel (2017) reported to have recorded a high zone of inhibition when leaf extract of $\mathrm{C}$. odorata was tested against pyogenic pathogens. Odinakachukwu et al., (2019) reported to have observed the antibacterial activity of leaf extract of Chromolaena odorata and the effect of its combination with some conventional antibiotics on pathogenic organisms isolated from wounds. Studies by Anibijuwon et al., (2010) and Obioma et al., (2017) reported antimicrobial activities of leaf extract of Aspilia africana on some pathogenic organisms of clinical and wound origin. Anyanwu and Nwosu (2014) and Olusimbo et al., (2011) reported antimcoribal activities of Piper guineense against some pathogens.

Amongst the plant extracts tested, P. guineense had the lowest minimum inhibitory concentration $(50 \mathrm{mg} / \mathrm{ml})$ against the ESBL producing E. coli and K. pneumonia investigated. Although, Gentamycin had a far lower minimum inhibitory concentration $(1.5 \mathrm{mg} / \mathrm{ml})$ against the isolates, however, all the plant extracts showed signs of antibacterial potency agent the tested isolates.

The medicinal value of a plant can be determined on the basis of bioactive compounds. Several reports by Olusimbo et al., (2011); Bassey et al., (2013); Anyanwu and Nwosu (2014) and Obioma et al., (2017) have recorded the presence of tannins, phenolic compounds, flavonoids, terpenoids, glycosides and alkaloids in extracts of C. odorata, A. afrciana, H. crinata, P.guineense and L. africana. The presence of these phyto-components plays a vital role in the antimicrobial properties of the plants. Alkaloids are major plant components responsible for antimicrobial activity. It intercalates with DNA and interferes with the cell division (Kigigha and Zige, 2013). Flavonoids are a major group of plant phenolic compounds that act as antioxidant. It forms a complex with extracellular soluble proteins, bacterial cell walls and also disrupts the cell membrane (Divya et al., 2014). Terpenoids are a subclass of prenylipids and are naturally occurring organic chemicals which damages the cell membrane (Bassey et al., 2013). Tannins are polymeric phenolic substances which precipitate microbial protein and also inactivate microbial adhesion, enzymes and cell wall envelope transport proteins (Hridhya and Kulandhaivel, 2017).

\section{Conclusion:-}

This study on the bactericidal and bacteriostatic potency of some phyto-bactericides against selected ESBL producing bacteria has revealed that the phyto-constituents of C. odorata, A. africana, H. crinata, P. guineense and L. africana have high antimicrobial property as compared and confirmed with commercial antibiogram. Since the drug resistance nature of bacteria have been reported to be on the increase as each day passes, these plant extracts could serve as an alternative medicine without side effects. In addition, these plants could further be used to discover other bioactive natural products that may serve as lead for the development for new phyto-pharmaceuticals.

\section{References:-}

1. Agbafor, N., Akubugwo, I., Oyabashi, E. \& Ukwandu, C. (2011). Chemical and antimicrobial properties of leaf extracts of Zapoteca portoricensis. Research Jounral of Medicinal Plant, 5, 605-612.

2. Andy, I.E., Tiku, D.R., Okpo, E.A. \& Utsalo, S. J. (2019). Prevalence and assessment of ESBL producing organisms in the South-South geopolitical zones of Nigeria. International Journal of Interdisciplinary Research and Innovations, 7(2), 27-39.

3. Anibijuwon, I., Duyilemi, O. \& Onifade, K. (2010). Antimicrobial activity of leaf of Aspila africana on some pathogenic organisms of clinical origin. Ethnobotanical leaflets, 14, 390-401.

4. Anyanwu, U. \& Nwosu, C. (2014). Assessment of antimicrobial activity of aqueous and ethanolic extracts of Piper guineense leaves. Journal of Medicinal Plant Research, 8(10), 436-440.

5. Bassey, N., Ogbemudia, O., Harold, O. \& Idung, E. (2013). Combined antifungal effects of extracts of J. curcus and C. Odorata on seed borne fungi. Bulletin of Environmental Pharmacology and Life Sciences, 2(2), 13-17.

6. Dhiman, A., Nanda, A., Ahmad, S. \& Narasimhan, B. (2010). In vitro antimicrobial activity of methanolic leaf extract of Psidium guajava. Journal of Pharmaceutical and Biological Sciences, 3, 226-229. 
7. Divya, S., Thenmozhi, T., Suresh, K. \& Selvan, M. (2014). Antibacterial activity of medicinal plant against wound infected pathogens. International Journal of Pharmaceutical Science and Research, 5(11),4942-4947.

8. Hridhya, V. \& Kulandhaivel, M. (2017). Antimicrobial activity of Chromolaena odorata against selected pyogenic pathogens. International Journal of Pharmacognosy and Phytochemical Research, 9(7), 1001-1007.

9. Ikegbunam, N., Anagu, O., Nwakile, C. \& Charles, O. (2014). Antimicrobial activity of selected medicinal plants of South- Eastern Nigeria on Pseudomonas species expressing Extended Spectrum Beta Lactamase (ESBL). European Journal of Medicinal Plants, 4(11), 1367-1377.

10. Kigigha, T. \& Zige, V. (2013). Activity of Chromolaena Odorata on enteric and superficial etiologic bacterial agents. American Journal of Research Communication, 1(11), 266-276.

11. Kiratism, P., Apisarhthanardk, A. \& Mundy, L. (2007). The emergency of novel ceftazidime CTX-M extended spectrum beta lactamase, CTX-M-55 in both community onset and hospital acquired infections in Thailand. Diagnostic Microbiology and Infectious Diseases, 58, 349-355.

12. Mukesh, R., Summit, J., Raj, K. \& Nehra, S. (2018). Antimicrobial activity of some Indian medicinal plants against the soil bacteria. International Journal of Pure and Applied Bioscience, 6(1), 461-466.

13. Muzaheed, Y., Dul., M. \& Paterson, I. (2008). High prevalence of CTX-M-15 producing Klebsiella pneumonia among in-patients with urinary tract infection in Southern India. Journal of Antimicrobial Chemotherapy, 62(6), 1393-1394.

14. Obioma, A., Chikanka, T. \& Dumo, I. (2017). Antimicrobial activity of leave extracts of Bryophyllum pinnatum and Aspilia africana on pathogenic wound isolates recovered from patients admitted in University of Port Harcourt Teaching Hospital, Nigeria. Annuals of Clinical Laboratory Research, 5(3), 185-189.

15. Odinakachukwu, O., Okechukwu, O., Ibuckukwu, O. \& Anthony, I. (2019). Antibacterial activity of leaf extract of Chromolaena odorata and the effect of its combination with some conventional antibiotics on Pseudomonas aeruginosa isolated from wounds. Journal of Applied Biology and Biotechnology, 7(3), 36-40.

16. Olusimbo, A., Abimbola, E. \& Chinonye, A. (2011). Antimicrobial activities of some Nigerian species on some pathogens. Agriculture and Biology Journal of North America, 2(8), 1187-1193.

17. Pena, C., Pujol, M. \& Ardanuy, C. (1988). Epidemiology and successful control of a large outbreak due to Klebsiella pneumonia producing extended spectrum $\beta$-lactamases. Antimicrobial Agents Chemotherapy, 42, 5358 .

18. Shahid, M., Malik, A. \& Sheeba, M. (2003). Multi-drug resistant Pseudomonas aeruginosa strains harbouring R-plasmids and AMPC $\beta$-lactamases isolated from hospitalized burn patients in tertiary care hospital of North India. FEMS letter, 228, 181-186.

19. Varalakshmi, B., Anand, V., Karpagam, I. \& Manikandan, R. (2014). In vitro antimicrobial and anticancer activity of Cinnamomum zeylanicum Linn bark extracts. International Journal of Pharmaceutical Science, 6(1), 12-18.

20. Winokur, L., Clinton, R. \& Legakis, N. (2001). Variations in the prevalence of strains expressing an extended spectrum $\beta$-lactamase phenotype and characterization of isolates from Europe, the Americans and the Western pacific region. Clinical Infectious Diseases, 32, 594-603. 